Persp. Teol. 42 (2010) 205-226

\title{
APOCALIPSE 12: UM CONJUNTO LITERÁRIO
}

\section{(Revelation 12: A literary combination)}

Anderson de Oliveira Lima*

RESUMO: Este artigo apresenta uma proposta para interpretar Apocalipse 12 a partir da análise da redação. Identificamos quatro unidades textuais independentes que foram costuradas pelo autor num único capítulo. Explicar como elas se relacionam para formar uma única e poderosa visão apocalíptica é o nosso objetivo.

PalAVRAS-CHAVE: Apocalipse, Exegese, Cristianismo Primitivo, Análise da redação.

ABSTRACT: This article introduces a proposal to interpret Revelation 12 starting from the writing analysis. We identify four independent textual units that were tied together by the author in a single chapter. Our objective is to explain how they interact to form a single and powerful apocalyptic vision.

KEY-WORDS: Revelation, Exegesis, Primitive Christianity, Writing analysis.

\section{Introdução}

o longo dos últimos dois milênios o misterioso Apocalipse de João
tem sido lido e interpretado de maneiras diversas. Para alguns o livro
causa admiração, curiosidade, para outros tantos, causa temor e é até evi-
tado. Isso não é de se admirar, pois um texto assim, repleto de símbolos
enigmáticos e ameaçadores, dá asas à imaginação dos seus leitores e torna-
se convidativo às múltiplas e contínuas interpretações. A história da recep-
ção do Apocalipse é testemunha de quantas e quão divergentes são as

* Universidade Metodista de São Paulo. Artigo submetido a avaliação no dia 16/10/2009

e aprovado para publicação no dia 10/11/2009. 
leituras feitas desse livro através da história ${ }^{1}$. Ainda assim, é possível identificar duas linhas principais nessa longa história da leitura.

Muitos dos leitores do Apocalipse tentam fazê-lo uma espécie de roteiro para os dias vindouros, interpretando-o como uma narração simbólica da história universal. Outros reduzem o livro a uma crítica política concernente aos primeiros anos do século II d.C., e apontam os possíveis paralelos existentes entre os elementos do texto e os fatos históricos da época da sua composição. Alexander L. Milton, que acredita que por trás dos textos existem verdadeiras experiências visionárias e escreve sobre a história da recepção do Apocalipse, comenta que qualquer um desses caminhos interpretativos tradicionais limita o conteúdo do livro:

[...] as interpretações prevalecentes dão ao Apocalipse ou um sentido histórico (o que significava na época em que foi escrito), ou futuro (um prognóstico do tempo do fim). No entanto, o Apocalipse se baseia numa verdadeira experiência visionária que transforma o autor pelo acesso a outras possibilidades, a uma outra maneira de se compreender em meio a um mundo hostil [...] É o próprio texto que promove uma interpretação particular e que revela que as tradições dominantes de interpretação do Apocalipse, viradas para a história ou para o futuro, são limitadas por não perceberem a verdadeira natureza das visões².

Milton parece ter razão; embora a identificação do Império Romano seja evidente nalguns momentos do livro, a grande perseguição contra os cristãos que parece envolver a sua composição não encontra testemunhos históricos convincentes. Tentando datar o livro nalgum momento histórico que dê motivos para as terminologias empregadas, que são próprias da perseguição do império contra os cristãos, costuma-se retroceder até os dias do imperador Domiciano (81-96 d.C.), o que suscita mais dúvidas do que soluções ${ }^{3}$. Quanto às tentativas de apresentar previsões futuristas a partir do livro, a necessidade de atualizar tais interpretações a cada gera-

\footnotetext{
${ }^{1}$ Uma breve história da interpretação do livro de Apocalipse pode ser lida em: B. MCGINN, “Apocalipse (ou Revelação)", in Guia Literário da Bíblia, São Paulo: Unesp, 1997, 563-582. ${ }^{2} \mathrm{Na}$ verdade, como o trabalho de Milton dedica-se à história da recepção, ele apresenta resenhas de duas obras publicadas recentemente que refletem, em sua opinião, o modo como tal disciplina tem sido vista na Grã-Bretanha. Dentre essas duas obras, uma comenta a história da recepção de Juízes, e outra, de J. Kovacs e C. Rowland, de Apocalipse. Ambos os livros foram publicados em 2004 em Oxford, pela Blackwell. A citação que fazemos é, portanto, parte do seu resumo a respeito da história da recepção do livro de Apocalipse. Cf. A.L. MILTON, "História da Recepção da Bíblia: Novos Enfoques na Pesquisa Britânica", Orácula 1 (2005) 84-99, aqui 88.

${ }^{3}$ Helmut Koester, por exemplo, escreve sobre as consequências limitadas da suposta perseguição sob Domiciano dizendo que elas foram insignificantes fora de Roma e, portanto, sem importância direta para a comunidade do Apocalipse. Ele apenas menciona, tentando ainda encontrar meios históricos para justificar o texto, alguns atritos em Éfeso decorrentes da construção de um Templo em honra ao imperador. Cf. H. KOESTER, Introdução ao Novo Testamento, vol. 2: História e Literatura do Cristianismo Primitivo, São Paulo: Paulus, 2005, 269-271.
} 
ção evidencia que essas leituras mais diziam a respeito dos seus leitores e intérpretes do que do conteúdo do livro propriamente dito. Quantos não são os papas, imperadores e ditadores que já não foram identificados com o anticristo do Apocalipse?

Neste estudo em que outra vez Apocalipse 12 será abordado, tentaremos nos manter livres tanto quanto possível das influências deixadas por essa longa história interpretativa. Mas como escapar de tão forte influência e dos resultados a que outros tantos já chegaram sem que isso signifique a inauguração de uma nova alegoria? Partiremos do pressuposto de que o texto foi composto seguindo uma elaborada técnica de justaposição de unidades textuais ${ }^{4}$. Em outras palavras, defenderemos a teoria de que em Apocalipse 12 não temos uma única cena narrativa contínua, coesa e de fácil compreensão, mas diversas cenas que são dispostas de uma maneira estratégica. Procuraremos demonstrar que as diversas unidades que foram costuradas para formar este capítulo não narram eventos diversos, mas que são diferentes formas de se contar a mesma história. Mostraremos também que em cada uma dessas unidades textuais são encontrados elementos similares que evidenciam a unidade do texto, provando que embora essas unidades sejam distinguíveis, são também inseparáveis, já que é objetivo do autor fazer com que usemos as imagens e símbolos de uma para interpretar outra. Então, é a partir da aceitação de que o texto foi produzido através dessa técnica elaborada de intertextualidade que encontraremos os critérios para a interpretação dos símbolos nele empregados. Embora esse pressuposto possa ser questionado, acreditamos que assim estamos seguindo um caminho interpretativo proposto pelo próprio texto, e que nos auxiliará a evitar os voos que poderiam facilmente nos conduzir a novas alegorizações ou a superinterpretações ${ }^{5}$.

Trataremos então de cada uma das suas unidades textuais individualmente, investigando-as e levantando as questões que cada uma, por si só, nos permitir. Por fim, voltaremos aos pressupostos apresentados nessa introdução tentando justificar por meio de evidências tiradas dos próprios tex-

\footnotetext{
${ }^{4}$ Segundo Edgard Leite, os autores do Talmud faziam suas interpretações das leis judaicas a partir de justaposições. Ou seja, para interpretar ou ilustrar um tema, empregavam na análise textos diversos, que aparentemente nada têm em comum. Isso talvez seja mais uma evidência de que os antigos estudiosos da religião judaica em geral, e não apenas o autor do Apocalipse, usavam esta técnica em seus escritos. Cf. E. LEITE, "Yeshu Ha Notzri e sua Viagem ao Egito: Uma Parábola Talmúdica", in Jesus de Nazaré: Uma Outra História, São Paulo: Annablume, 2006, 279-292, aqui 284-285.

${ }^{5}$ É a partir das sugestões de Umberto Eco que aqui dizemos que o próprio texto pode indicar os caminhos para a sua interpretação. Segundo ele, quando o leitor não reconhece os limites impostos pelo próprio pode criar interpretações incoerentes com o que chama de intentio operis, ou intenção do texto. Essa intenção do texto que para Eco é sugerida pelo próprio, conduz o intérprete a interpretações mais coerentes do que a intenção do autor, que quase sempre se mostra inatingível, e que a intenção do leitor, que por falta de critérios pode produzir resultados infelizes. Cf. U. ECO, Interpretação $e$ Superinterpretação, São Paulo: Martins Fontes, 2005.
} 
tos que a justaposição de unidades textuais foi a estratégia adotada para a composição de todo esse capítulo. Assim, esperamos defender nossa tese sobre a composição do texto, e consequentemente sobre a maneira de interpretá-lo, e também apresentar nossa interpretação como prova da eficácia do método utilizado.

\section{1 - Primeira Unidade Textual: A Mulher e o Dragão (v. 1-6)}

Para aprofundar e facilitar nossa análise do texto, o apresentaremos em sua língua de origem ${ }^{6}$ e dividido versículo por versículo, e exatamente ao lado, uma tradução literal para o português preparada especialmente para este estudo:

\begin{tabular}{|c|c|}
\hline 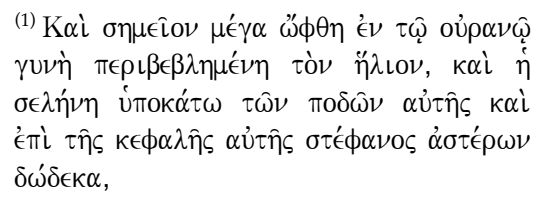 & $\begin{array}{l}\text { (1) E sinal grande foi visto no céu, } \\
\text { (uma) mulher tendo vestido o sol, e a } \\
\text { lua debaixo dos pés e sobre a cabeça } \\
\text { dela (uma) coroa de doze estrelas, }\end{array}$ \\
\hline 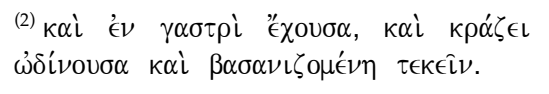 & $\begin{array}{l}\text { (2) e no ventre tendo, e grita com dores } \\
\text { de parto e atormentada para parir. }\end{array}$ \\
\hline 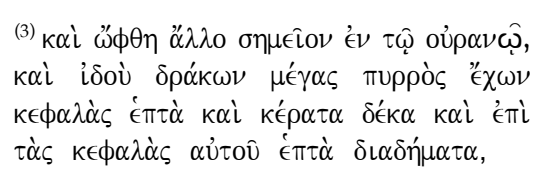 & $\begin{array}{l}{ }^{(3)} \text { E foi visto outro sinal no céu, e eis } \\
\text { dragão grande vermelho tendo sete } \\
\text { cabeças e dez chifres e sobre as cabe- } \\
\text { ças dele sete diademas, }\end{array}$ \\
\hline 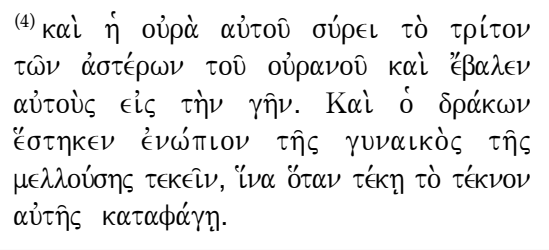 & $\begin{array}{l}{ }^{(4)} \text { e a cauda dele arrasta a terça parte } \\
\text { das estrelas do céu e lançou elas para } \\
\text { a terra. E o dragão para diante da } \\
\text { mulher que estava para parir, para } \\
\text { que quando parisse a criança dela de- } \\
\text { vorasse. }\end{array}$ \\
\hline 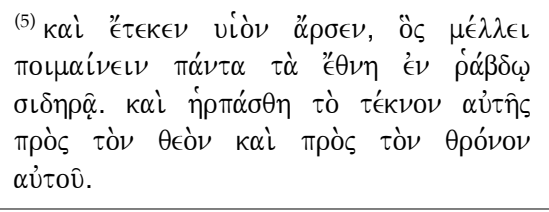 & $\begin{array}{l}{ }^{(5)} \text { E pariu um filho macho, o qual vai } \\
\text { reger todas as nações com cetro de } \\
\text { ferro. E foi tomada a criança dela para } \\
\text { Deus e para o trono dele. }\end{array}$ \\
\hline 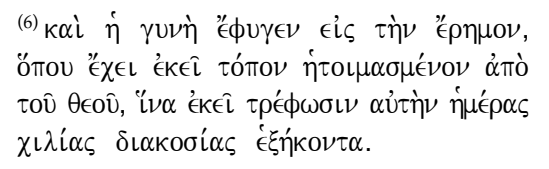 & $\begin{array}{l}\text { (6) E a mulher fugiu para o deserto, } \\
\text { onde tem ali lugar preparado de } \\
\text { Deus, para que ali alimente a ela por } \\
\text { dias mil duzentos (e) sessenta. }\end{array}$ \\
\hline
\end{tabular}

${ }^{6}$ Todos os textos gregos usados são de E. NESTLE / K. ALAND, Novum Testamentum Graece, $27^{\mathrm{a}}$ ed. 
A primeira das unidades textuais funciona bem como introdução ao capítulo, assume a responsabilidade de em seu princípio quebrar o silêncio narrativo e apresentar um a um os personagens que estarão em destaque. Esses personagens aparecem através de sinais no céu, os quais o visionário (narrador) vê e descreve. Ele não apenas trata das características "físicas" dos personagens, mas também de outras peculiaridades, que dizem respeito ao papel dos mesmos na história do cosmos como um todo. No entanto, o clímax dessa primeira seção se dá quando o texto termina as apresentações e entra na ação, fazendo com que os personagens interajam entre si.

\section{1 - Primeiro Sinal - A Mulher (v. 1-2)}

O primeiro dos sinais vistos no céu é uma mulher. Sua identidade não é apresentada com clareza nesta primeira aparição, mas através de símbolos, como é típico do Apocalipse. O texto nos diz que a mulher está envolvida pelos astros, que a servem como objetos de adorno. Rodeada por elementos da criação, a figura da mulher é captada pela imaginação do leitor como uma espécie de realeza; dentre as obras de Deus ela parece ser a principal, e no texto toda a criação parece existir apenas para servi-la. É bem possível que tenhamos aqui o emprego de uma imagem do Antigo Testamento. Em Gênesis 37,9-10, um outro personagem de prestígio sonha que o sol, lua e estrelas se curvam perante ele. Os familiares de José logo compreendem que o significado do sonho era que ele seria o senhor deles. Deveras tudo indica que a apresentação da mulher pretende transmitir-lhe uma nobreza similar.

Passando para a segunda parte da apresentação da mulher, vemos que apesar da sua posição privilegiada, a mulher está prestes a dar à luz, e por isso grita de dor e atormenta-se. Esta é uma informação que parece negativa à primeira vista, todavia, ao longo de toda a literatura bíblica a esterilidade era um mal bem mais temível que as dores de parto. Não estamos afirmando ainda que a dor que atormenta a mulher deve ser entendida num sentido positivo, queremos apenas nos prevenir para que não condicionemos nossa leitura pela possível má impressão que o texto nos transmite neste ponto através das palavras "grita com dores de parto e atormentada para parir", pois a intenção do texto pode ser bem outra.

Voltaremos a tratar da mulher noutros momentos, mas por ora, fundamentando-nos apenas nos primeiros dois versículos, essas são algumas das poucas conclusões a que o texto nos conduz.

\section{2 - Segundo Sinal - O Dragão (v. 3-4)}

O segundo sinal que também é visto no céu é um grande dragão vermelho, figura que em oposição ao esplendor da mulher, apresenta-se tenebrosa. Além de ser um dragão, de ser grande e de ter uma cor vermelha como fogo, outras características sombrias desse personagem merecem destaque: 
O dragão possui sete cabeças com sete diademas nelas, talvez imagens que simbolizem realezas ou imperadores. Em todo caso, o dragão também possui dez chifres, o que desde o livro apocalíptico de Daniel são símbolos conhecidos para representar governantes (Dn 7,24; 8,20), conforme também se vê em Apocalipse 17,12. Assim, enquanto a mulher era adornada pelos astros, o dragão exibe reis e imperadores, é adornado por símbolos de poder humano.

No versículo 4, em que é apresentado o papel do dragão no cosmos, lê-se que o dragão conturbava a ordem dos astros e da terra, promovendo o caos na própria criação. Assim, ele prejudicava indiretamente a mulher, que é pelos astros adornada, e a ameaça diretamente tentando devorar seu filho. O autor dá destaque à relação de ódio que há entre o dragão e o filho que ainda nem nascera, logo, entendemos que o nascimento da criança deve representar alguma forma de ameaça ao poder do dragão. Em resumo, a mulher é adornada pelos astros que o dragão ataca, e por sua vez, o dragão é adornado por poderes terrenos, que o filho da mulher ameaça. Enfim, já na apresentação dos dois primeiros personagens temos um cenário de guerra bem desenhado. Mulher e dragão são símbolos de duas forças que se opõem, e a grandeza desse embate alcança toda a criação.

\section{3 - O Nascimento do Filho (v. 5a)}

O terceiro personagem não é como os outros; ele não é visto no céu, mas nasce da mulher. Apenas duas coisas são ditas a seu respeito, e parecem muito significativas: primeiro, ele é um homem, e governará todas as nações do mundo com cetro de ferro. Então seu destino está escrito, ele será um governante, e não qualquer governante, mas o maior deles. É por estar destinado a ser o único governante das nações que o filho é odiado pelo dragão; ele representa a sua derrota. Confirma-se então que o dragão é um ser que se exibe por ter consigo o poder político. Agora a ameaça do dragão ao menino nos é compreensível, e sua atitude de atacá-lo imediatamente após o nascimento é uma espécie de ação preventiva; quer destruir o adversário antes que se torne mais poderoso que ele.

O cetro de ferro simboliza a maneira com o qual o filho da mulher exercerá seu poder. Símbolo da autoridade real, por ser feito de ferro o cetro evidencia a força irresistível, a indestrutibilidade do reino do filho.

\section{4 - Acontecimentos Seguintes (v. 5b-6)}

Os personagens foram apresentados e os motivos da batalha em que estão envolvidos foram brevemente citados; agora, a unidade textual caminha em direção à conclusão com a narração dos acontecimentos que anteriormente foram preparados. Este é o clímax da primeira unidade textual de Apocalipse 12, como já dissemos. 
Então a mulher dá à luz seu filho, mas o dragão, embora astuto, não o devora como planejava. O menino é salvo por um ato de Deus, o que nos mostra de uma vez por todas que os "mocinhos" da história são o menino e a mulher. Após o milagre que salva o menino, Deus o leva para o seu trono. Essa referência ao trono de Deus pode ser significativa; talvez ele tenha sido levado para lá a fim de que dali exerça o governo sobre as nações conforme já se anunciou. Seguro é que Deus zela pelo menino, e está disposto a agir para que o destino anunciado para ele se concretize.

O dragão teve seus planos frustrados e aparentemente nada pode fazer contra a decisão de Deus. Consequentemente, ele sabe que seu governo está com os dias contados. Se aquele garoto logo tomará a cena e despojará do dragão todo o poder que exerce sobre o mundo, o identificamos exercendo uma função evidentemente messiânica. $\mathrm{O}$ menino que acabara de nascer e foi levado para Deus, é a promessa de que no futuro um novo governo será levantado, pondo fim aos poderes terrenos atuais que são controlados pelo dragão. Embora o texto não o diga abertamente, é possível identificar o menino com o messias a partir desses detalhes, e sendo o texto fruto de uma comunidade cristã, podemos dizer sem reservas que o menino é o Cristo.

Também podemos imaginar nesse ponto do texto que o dragão ficara irado após o arrebatamento do menino, e que poderia voltar sua ira contra a mulher, que ficara no mundo. Por isso o último versículo diz que a mulher fugiu para o deserto, para o lugar que Deus tinha preparado. Ali ela seria sustentada por mil duzentos e sessenta dias, ou quarenta e dois meses, ou três anos e meio. A referência ao deserto sempre nos faz lembrar o êxodo do Antigo Testamento, e a ideia de ficar refugiada e sendo alimentada por Deus, nos remete ao profeta Elias. Pensar em Moisés e Elias não é um equívoco neste caso, e nos dá as primeiras indicações de que esta mulher é uma espécie de "profetiza", de autoridade espiritual prodigiosa ou mediadora entre Deus e os homens. Como identificamos o menino com o messias, sua mãe pode ser identificada com a nação que dá à luz o messias, que é Israel. Não poderíamos dizer que ela é a Igreja, pois a mulher precede ao Cristo.

Então, o menino era o messias, mas sua vinda não trouxe ao mundo a revolução esperada. Ele nasceu fraco, como um menino, e foi tirado da terra por Deus quando o dragão o procurava destruir. Agora, aquele indefeso garoto aguarda o momento certo para talvez regressar e assumir o poder que lhe foi dado sobre toda a criação de Deus. Enquanto a comunidade cristã (que ainda não se vê desligada do Israel do Antigo Testamento) aguarda o retorno do Cristo, suporta as carências naturais do deserto, local onde novamente o povo de Deus espera pela vitória. Os três anos e meio que ela ficaria refugiada deve ser o tempo previsto para que o menino pudesse amadurecer e assumir o poder. Não sabemos se este período deve ser entendido literalmente. 
A volta ao deserto por parte dessa mulher é outro problema para a exegese. Certamente a nação de Israel não voltou inteira a peregrinar pelo deserto, o que pode nos indicar que tal fuga seja apenas simbólica. Ou então, essa mulher não represente toda a nação de Israel, mas uma parte dela, um grupo que como muitos outros se considerava o "verdadeiro Israel" e que agora vivia fora do território palestinense. Seriam então judeus cristãos da diáspora, que interpretavam o momento em que viviam como um tempo de peregrinação semelhante ao êxodo, e aguardavam o retorno do Messias para voltarem vitoriosos à sua terra. Essa segunda hipótese nos parece bastante plausível.

O dragão será claramente identificado com Satanás na próxima unidade textual, todavia, nesta primeira, como nós o vemos ligado aos símbolos do poder terrenos, podemos também conjeturar sobre sua atuação na vida da comunidade cristã. Satanás age no mundo através de agentes humanos ${ }^{7}$, especialmente pelos líderes políticos, e não seria ir muito longe supor que toda a atuação do dragão nesta primeira unidade textual corresponda à ação do Império Romano. A permanência dessa comunidade longe da Palestina, e a morte do Messias, são fatos que parecem ter sido atribuídos aos romanos. Neste caso, temos uma comunidade cristã da diáspora que já não segue a interpretação de outros cristãos que, durante os embates entre os judeus cristãos e não-cristãos nas décadas que se seguiram à guerra judaica e à destruição do Templo de Jerusalém, culparam os judeus pela morte de Jesus (cf. Mt 27,24-25). Para os membros dessa comunidade cristã que produziu o Apocalipse, a cisão entre os judeus que criam em Jesus e os demais é um trauma superado, e o único inimigo que merece destaque é o Império.

\section{5 - Para Seguir com a Exegese}

A identificação que fazemos dos personagens das narrativas com Israel, Jesus e o demoníaco Império Romano, obviamente nos mostra que a leitura do texto de Apocalipse 12 era, desde o princípio, um exercício de interpretação de símbolos míticos para a compreensão da realidade vivenciada pela comunidade cristã. Esta linguagem, todavia, era apenas uma forma apocalíptica de descrever as peculiaridades da fé cristã de uma comunidade ainda em processo de desenvolvimento e institucionalização. Nas análises que faremos a seguir, continuaremos a usar a linguagem simbólica do texto, evitando que a interpretação dessa primeira unidade condicione nossas próximas leituras. Assim, caso a mulher volte a aparecer noutra

\footnotetext{
${ }^{7}$ Acreditava-se que Satanás possuía algumas pessoas e conduzia seus atos vis. Este é o caso, por exemplo, de Judas Iscariotes. O ato de traição de um dos doze discípulos mais próximos de Jesus talvez fosse incompreensível para muitos, e por isso é explicado por Lucas como um gesto feito sob a influência satânica. Cf. Lc 22,3.
} 
unidade textual, não a identificaremos com Israel se o texto assim não nos mostrar. Deixaremos, então, que as narrativas independentes sejam analisadas individualmente até a nossa última seção.

Para que não estraguemos a expectativa que a narrativa pretende suscitar, esqueçamos por algum tempo que se trata de uma comunidade cristã e da história de Jesus de Nazaré, e voltemos a nos fazer curiosos para conhecer o desenrolar da história e seus personagens misteriosos. O que será do menino que foi tomado para o trono de Deus? E a mulher, o que acontece com ela no deserto e depois que sai dele? E quanto ao dragão, o que faz após ver seus planos frustrados? Ele permanece na espera de uma oportunidade para atacar a mulher e seu filho? Essas são as perguntas que um leitor que jamais teve contato com o cristianismo se faria ao ler a primeira narrativa. Sob este ponto de vista, as respostas a essas perguntas são mais significativas para o texto em si do que aquelas ligadas à fé de leitores já "cristianizados".

\section{2 - Segunda Unidade Textual: Guerra no Céu (v. 7-9)}

A segunda narrativa começa dizendo: "E fez-se guerra no céu...". Pode-se dizer que a batalha celestial é o tema central dessa nova seção narrativa, embora tenhamos visto que na anterior também existe uma espécie de batalha entre os personagens.

\begin{tabular}{|c|c|}
\hline 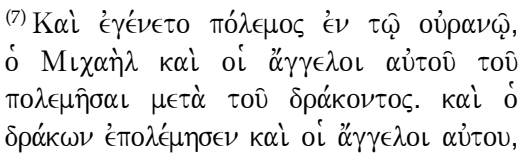 & $\begin{array}{l}{ }^{(7)} \text { E fez-se guerra no céu, Miguel e os } \\
\text { anjos dele para guerrear com o dra- } \\
\text { gão. E o dragão guerreou e os anjos } \\
\text { dele, }\end{array}$ \\
\hline 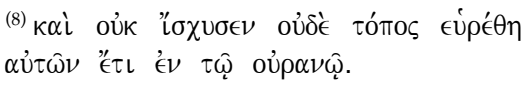 & $\begin{array}{l}{ }^{(8)} \text { e não foi forte nem lugar foi acha- } \\
\text { do deles mais no céu. }\end{array}$ \\
\hline 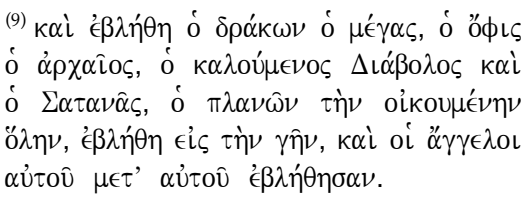 & $\begin{array}{l}\text { (9) E foi lançado o grande dragão, a } \\
\text { antiga serpente, chamado Diabo e Sa- } \\
\text { tanás, o que faz errar o mundo todo, } \\
\text { foi lançado para a terra, e os anjos } \\
\text { dele com ele foram lançados. }\end{array}$ \\
\hline
\end{tabular}

Miguel e seus anjos aparecem na história lutando contra o dragão. Temos uma batalha celestial tipicamente apocalíptica, em que não há qualquer espaço para a atuação humana. O destino da humanidade está sendo decidido nos céus, e nós, leitores ou ouvintes, somos meros expectadores das 
coisas que acontecem nas regiões celestiais. Importante é o versículo 9, que esclarece a identidade do dragão, que pode ser chamado de Diabo ou Satanás, e que também é identificado com a antiga serpente de Gênesis 3, responsável por fazer pecar toda a humanidade. Na batalha, o dragão e seus anjos não foram fortes o bastante, e por isso aquele que anteriormente surgira numa visão celestial perde seu lugar nos céus. Ele é banido, lançado à terra, e com ele os seus anjos.

Quanto a Miguel, um personagem que surge sem apresentações (talvez por ser bem conhecido na época), parece ser simplesmente um anjo poderoso, um líder desse exército que luta contra o dragão, a exemplo do que lemos no livro de Daniel (caps. 10 e 12). Contudo, vale dizer que a tradição religiosa judaica em suas múltiplas formas forneceu às primeiras gerações cristãs elementos suficientes para que Miguel fosse identificado, juntamente com Melquisedeque e o Filho do Homem, com uma espécie de messias angelomórfico. Daí vê-se nos testemunhos cristãos primitivos que o próprio Jesus por vezes foi confundido com tais personagens ${ }^{8}$. Todavia, não nos parece sensato julgar que este é o caso aqui. Miguel é uma espécie de líder dos exércitos celestiais, e impõe sobre seu inimigo uma primeira derrota.

Continuando nossa leitura, vemos que aqui o dragão ao descer não arrasta estrelas com a cauda lançando-as à terra como lemos na unidade anterior (v. 4), mas é lançado juntamente com seus anjos. As similaridades são mais significativas que as diferenças neste caso, e nos levam a crer que temos duas versões do mesmo fenômeno, duas narrativas escritas com o objetivo de contar um mesmo episódio, porém, sob pontos de vista bem diferentes. Há uma origem comum para essas duas versões, um mito que procurava explicar a presença do mal no mundo contando como o dragão veio até aqui para nos atormentar. Lucas 10,18 é prova de que esta imagem estava bem estabelecida no cristianismo, e é muito provável que o mesmo mito possuísse várias versões dissonantes na época da composição do Apocalipse. Uma dessas versões está aqui reproduzida, onde o Diabo foi lançado à terra após perder a batalha contra Miguel. Esta versão é diferente da anterior, em que ele desce à terra aparentemente por vontade própria arrastando as estrelas (anjos) do céu. Nessa compilação de textos tais diferenças não foram consideradas decisivas; não existia na mente desse compilador a necessidade de se escolher uma das versões reconhecendo-a como a mais verdadeira, pois ambas eram-lhe satisfatórias e cumpriam seus propósitos.

Tentar encontrar algum seguimento cronológico entre esta unidade e a anterior é um problema a ser evitado, uma armadilha em que caem os intérpretes que ignoram a estratégia da justaposição de textos. Antes de tentar harmo-

${ }^{8}$ Cf. L. SCHIAVO, "A Fonte dos Ditos de Jesus e as Raízes da Cristologia”, in Jesus de Nazaré: Uma Outra História, 193-216. 
nizar as duas narrativas, encaremos cada uma dessas unidades bem delimitadas como um texto independente. Deixemos para o final as perguntas sobre qual ou quais os efeitos pretendidos desse agrupamento de textos.

\section{3 - Terceira Unidade Textual: Um Hino de Vitória (v. 10-12)}

\begin{tabular}{|c|c|}
\hline 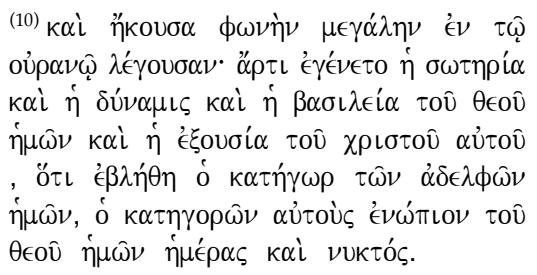 & $\begin{array}{l}{ }^{(10)} \text { E ouvi grande voz no céu dizendo: } \\
\text { Agora veio a salvação e o poder e o } \\
\text { reino do nosso Deus e a autoridade } \\
\text { do Cristo dele. Pois foi lançado o } \\
\text { acusador dos irmãos nossos, o que } \\
\text { acusa eles diante do nosso Deus dia } \\
\text { e noite. }\end{array}$ \\
\hline 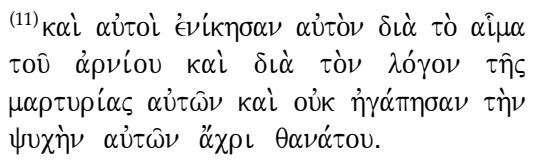 & $\begin{array}{l}\text { (11) E eles o venceram por meio do } \\
\text { sangue do cordeiro e por meio da pa- } \\
\text { lavra do testemunho deles e não } \\
\text { amaram a vida deles até a morte. }\end{array}$ \\
\hline 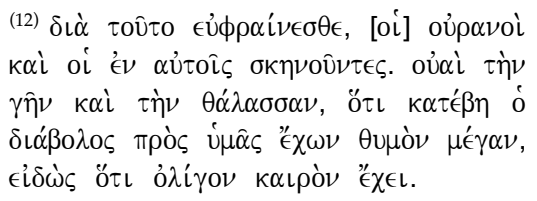 & $\begin{array}{l}{ }^{(12)} \text { Por isto alegrem-se, [os] céus e os } \\
\text { que neles habitam. Ai da terra e do } \\
\text { mar, pois desceu o diabo para vós } \\
\text { tendo grande ira, sabendo que pouco } \\
\text { tempo tem. }\end{array}$ \\
\hline
\end{tabular}

Temos, nesse trecho, um gênero literário diferente dos empregados anteriormente. $\mathrm{O}$ texto narrativo que predomina em todo o livro é substituído aqui por formas poéticas, e além disso, a linguagem mítica é trocada por uma linguagem litúrgica. Formulada a partir de um novo campo semântico mais eclesial, esta unidade expressa-se com maior clareza que as anteriores, e pode iluminar-nos quanto às leituras que o próprio compilador fazia dos elementos míticos.

O texto começa com uma introdução em primeira pessoa (E ouvi grande Voz no céu dizendo:), e segue-se uma sequência de expressões que caracterizam o novo tempo que a "grande voz" anuncia:
Agora veio a salvação
e o poder
e o reino do nosso Deus
e a autoridade do Cristo dele. 
Essas expressões não são repetições umas das outras, mas estão inegavelmente relacionadas por um eixo paradigmático, seguindo padrões comuns da antiga poesia hebraica. Todas elas fazem parte de um mesmo campo semântico que ia se tornando próprio do cristianismo, palavras que falam de Jesus como salvador e rei. O jogo de palavras que caracteriza o texto como poesia também é identificado no cruzamento entre Deus e Cristo, e entre os pronomes possessivos ligados a eles (nosso, dele). A voz proclama uma nova realidade no céu (Agora veio...). Ela já nos diz o que veio: uma espécie de reino de Deus em que Cristo e Deus se misturam na figura de um governante poderoso. O reino é de Deus, mas a autoridade é de Cristo, caracterização que dentro do cristianismo não é necessariamente um paradoxo.

O reino veio, mas como veio? A resposta a esta pergunta é o que lemos a seguir:

E eles o venceram por meio do sangue do cordeiro

e por meio da palavra do testemunho deles

e não amaram a vida deles até a morte.

A vinda do reino aconteceu por meio de uma vitória. Esta vitória, porém, não parece estar relacionada às batalhas cósmicas lidas nas narrativas precedentes (vv. 1-9). Aqui, a morte sacrificial de Jesus e dos seus seguidores (mártires) determinaram a vitória. Quer dizer que, mesmo diante de outra batalha vencida e de uma espécie de celebração por tal feito, agora quem venceu a batalha não foi mais Miguel e seus anjos, mas os cristãos que com sua morte deram o mais forte testemunho a respeito de sua fé.

No texto podemos ver a relação que há entre o sacrifício de Cristo (sangue do cordeiro) e a morte dos cristãos (palavra do testemunho [martiria] deles). Essa sujeição que torna digna a morte dos fiéis perseguidos, considerada uma entrega voluntária da vida por amor e fidelidade a Deus, é apresentada como uma arma que vence Satanás. Temos uma hermenêutica própria de uma comunidade cristã ameaçada que cria sua identidade por meio da perseguição sofrida. Não parece haver dúvidas de que esta unidade textual nasceu de forma independentemente das demais; outra vez o que nos surpreende é o fato de o compilador atribuir pouca importância às contradições, aceitando costurar tais textos como se de alguma forma eles se harmonizassem. A derrota e a queda do dragão é o tema que unifica os textos, e pede que ignoremos os demais problemas. 
No versículo $12 \mathrm{ab}$ temos mais duas frases que se relacionam:

Por isto alegrem-se, [os] céus e os que neles habitam.

Ai da terra e do mar,

Essas duas frases respondem a outras perguntas sobre a chegada do reino. A primeira é: aonde veio? A resposta é que o reino é chegado apenas nos céus. Neste ponto vale a pena observar que o reino de Deus que Jesus proclamava perdera sua vocação histórica antes que se completasse um século de sua morte ${ }^{9}$. Consequentemente, o leitor, que não está nos céus, perguntará: e a terra, como fica? A resposta é expressa num sucinto "ai", expressão de lamento fúnebre que insinua um destino trágico para a terra e o mar.

Embora a relação entre as duas frases seja óbvia, cada uma destina-se a um público. A primeira é uma espécie de exortação à exultação pela vitória. A voz pede que os céus e seus habitantes alegrem-se pela vitória sobre Satanás e pela chegada do reino de Deus. $\mathrm{O}$ acusador já não tem acesso a Deus, não pode acusar mais ninguém, e a vitória contra toda acusação se deu exatamente porque pessoas provaram-se inculpáveis pelo martírio. Quer dizer: o que se pode falar contra alguém que dá a vida por aquilo que defende? Os mártires são santos, venceram o acusador, calaram-no definitivamente. Eles provavelmente estão entre os habitantes do céu que agora podem se alegrar. Assim, a razão de toda exultação é a vitória que purificou o céu excluindo dele o acusador. Podemos, para facilitar a visualização e a compreensão do texto, ligar os versículos 12a e 10b da seguinte forma:

Por isto alegrem-se, os céus e os que neles habitam. (v. 12a)

Pois foi lançado o acusador dos irmãos nossos,

o que acusa eles diante do nosso Deus dia e noite. (v. 10b)

\footnotetext{
${ }^{9}$ Para tratar melhor sobre essa vocação histórica (terrena) que o reino de Deus proclamado pelo Jesus histórico possuía, citamos B. MALINA, O Evangelho Social de Jesus: O Reino de Deus em Perspectiva Mediterrânea, São Paulo: Paulus, 2007, 146: "Proclamando o reino de Deus e Deus como patrono, Jesus estava apresentando soluções para os problemas sociais existentes. O reino de Deus dominaria sobre as difundidas doenças geradas pelo mau funcionamento ou não-funcionamento do sistema político. A mensagem
} 
A segunda frase dirige-se à terra e ao mar, ao local desventurado que recebe Satanás e seus anjos derrotados e cheios de ira. O mesmo evento que trouxe alegria ao céu traz problemas à terra. $O$ final da narrativa apresenta esse quadro incompleto e preocupante:

Ai da terra e do mar,

pois desceu o diabo para vós tendo grande ira,

sabendo que pouco tempo tem. (v. 12bc)

A ira do diabo está ligada e é proporcional ao pouco tempo que ele tem na terra. Espera-se que ele vá agir depressa para trazer destruição ao mundo, mas a esperança é encontrada na afirmação de que ele tem pouco tempo. Apesar de toda a cena celestial, imaginamos que o ponto mais relevante para os cristãos da época é o final, que procura explicar, como nas unidades anteriores, a presença do mal no mundo. A mensagem deste hino procurava conformar os leitores e ouvintes que se debatiam com as dificuldades inerentes à existência humana, que eram agravadas pela opção de fé deles. A morte era vista como uma possibilidade real, que deveria ser enfrentada com fé caso os ameaçasse diretamente.

Nota-se que em toda a análise desta terceira unidade distanciamo-nos consideravelmente dos temas apresentados nas unidades anteriores. Todavia, não se deve julgar que o autor compilou tais textos de forma descuidada; antes, procuraremos entender os motivos que o levaram a juntar estes textos de origem diversa. Por enquanto, sabemos que há um tema recorrente em todas as unidades estudadas, que é a descida de Satanás ao mundo. Ainda que em cada caso essa descida apresente-se de maneira própria, este tema pode ser central no capítulo e justificar a compilação de textos feita em Apocalipse 12.

de Jesus constrangia os israelitas a suportar o presente e olhar em frente para o que estava vindo: uma nova teocracia política na qual Deus seria o patrono de Israel". Nossa observação procura destacar que em Apocalipse 12 o reino de Deus nada tem a ver com os problemas sociais, pois é um fenômeno celestial instaurado pela ausência de Satanás. Assim como tudo o que havia no céu retratava uma realidade ideal a se concretizar no mundo terreno, também o reino de Deus era ainda uma expectativa futura, que se daria não mais pela atuação dos homens em sua vida cotidiana, mas pela intervenção divina em sentido apocalíptico. 


\section{4 - Quarta Unidade Textual: A Perseguição à Mulher (v. 13-17)}

\begin{tabular}{|c|c|}
\hline 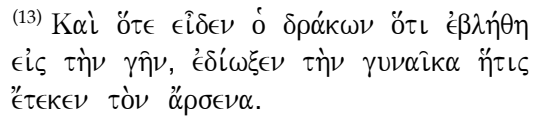 & $\begin{array}{l}{ }^{(13)} \text { E quando viu o dragão que foi lan- } \\
\text { çado para a terra, perseguiu a mu- } \\
\text { lher que pariu o macho. }\end{array}$ \\
\hline 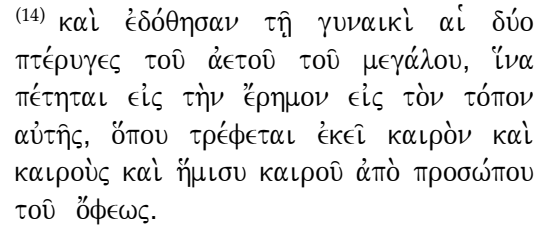 & $\begin{array}{l}{ }^{(14)} \text { E foram dadas à mulher as duas } \\
\text { asas da grande águia, para que voas- } \\
\text { se para o deserto para o lugar dela, } \\
\text { onde alimentada ali tempo e tempos } \\
\text { e meio tempo longe da face da ser- } \\
\text { pente. }\end{array}$ \\
\hline 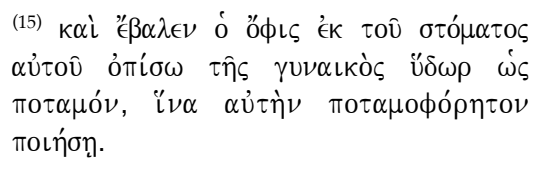 & $\begin{array}{l}{ }^{(15)} \text { E lançou a serpente da boca dela } \\
\text { atrás da mulher água como (uma) tor- } \\
\text { rente, para que ela levada fizesse. }\end{array}$ \\
\hline 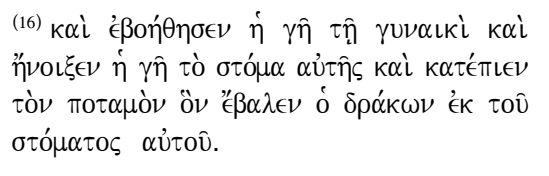 & $\begin{array}{l}\text { (16) E ajudou a terra à mulher e abriu } \\
\text { a terra a boca dela e engoliu a torren- } \\
\text { te a qual lançou o dragão da boca } \\
\text { dela. }\end{array}$ \\
\hline 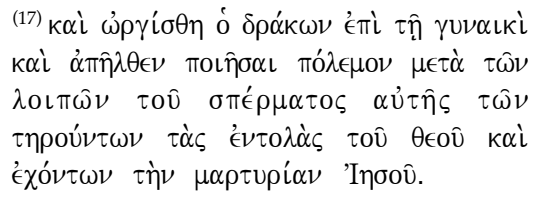 & $\begin{array}{l}\text { (17) E foi irritado o dragão contra a } \\
\text { mulher e foi fazer guerra com os re- } \\
\text { manescentes da semente dela os que } \\
\text { guardam os mandamentos de Deus e } \\
\text { têm o testemunho de Jesus. }\end{array}$ \\
\hline
\end{tabular}

Para fechar o conjunto literário do capítulo 12 fez-se uso de expressões que aproximam esta última unidade da primeira. $\mathrm{O}$ texto volta a retratar a mulher que pariu o macho e sua fuga para o deserto em termos bem

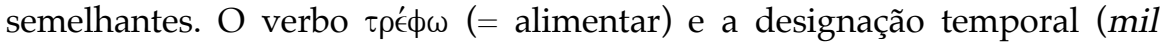
duzentos [e] sessenta dias) que marcam a conclusão do versículo 6, reaparecem no versículo 14 . O dragão que na primeira unidade acentua o estado de crise querendo devorar o filho da mulher, agora vê a torrente que lançara contra ela ser engolida pela terra. Claramente o conjunto textual está sendo fechado, emoldurado pela reapresentação dos temas. Novamente constata-se a impossibilidade de ler o capítulo numa sequência cronológica; na verdade, o retorno aos elementos que marcavam a primeira unidade sugere, à primeira vista, uma leitura cíclica, encontrada também em outros pontos do mesmo livro. 
Além disso, também vemos ligações, dessa vez na sequência narrativa, desta unidade com a segunda. É bastante nítido que o início "E quando viu o dragão que foi lançado para a terra..." é a continuação de uma narrativa que contava a queda do dragão. Então, nossa opinião é que as segunda e quarta unidades fossem uma só antes da redação do Apocalipse de João. Era um mito que contava como Satanás veio parar no mundo depois de perder uma batalha cósmica, e como, depois disso, ele volta-se contra uma mulher que passava por provações no deserto. A "serpente" é um epíteto para dragão que aparecera pela primeira vez no versículo 9 e só volta a se repetir nesta quarta unidade (vv. 10-11), dando-nos outra prova de que se trata de uma só narrativa. Na terceira unidade, este personagem é chamado apenas de acusador e diabo, nomes que ou não aparecem ou não são tão importantes nas demais; e na primeira unidade, que conta com outras palavras aquilo que esta quarta unidade traz, apenas o epíteto dragão é usado.

Ao mesmo tempo em que encontramos motivos para unir as unidades segunda e quarta atribuindo-as à mesma autoria, encontramos motivos para acreditar que as demais foram compostas de maneira independente. A ligação da fuga para o deserto com o êxodo torna-se mais evidente nesta quarta unidade do que na primeira, principalmente pelo uso que se faz das "asas da grande águia", uma imagem do Antigo Testamento claramente copiada aqui (Ex 19,4 e Dt 32,11). Na primeira narrativa, a mulher fugira para o deserto onde parecia estar protegida contra o dragão. Aqui, o dragão continua a atacar a mulher mesmo após sua fuga. Essa versão faz um uso mais comum do deserto como figura bíblica. Normalmente na literatura bíblica andar pelo deserto é sinônimo de provação, e isso se vê na história do Êxodo e também nas tentações de Jesus (Lc 4,1-2). Ou seja, o emprego do deserto como referência topográfica na primeira unidade textual não transmite com a mesma clareza o sentido de provação que se pretendia, mas através da compilação desta outra versão, qualquer dúvida quanto a isso é dissipada. Temos duas versões da mesma história, compostas de maneira independente e reunidas aqui em Apocalipse 12 para formar um quadro mais completo.

Lemos nesta última parte que a serpente lança água como uma torrente de sua boca, mas a terra ajuda a mulher abrindo sua boca e engolindo a torrente. Talvez exista também uma referência a Números 16, em que a terra cumpre a vontade de Deus e engole os inimigos. Irado por perder também a batalha contra a mulher, outra vez por uma intervenção milagrosa de Deus no momento exato, o dragão "foi fazer guerra com os remanescentes da semente dela, os que guardam os mandamentos de Deus e têm o testemunho de Jesus".

Apesar das diversas vitórias, a guerra não termina e o texto acaba com a serpente perseguindo os remanescentes da semente da mulher. Uma nova 
batalha está encaminhada contra os que guardam os mandamentos de Deus e têm o testemunho de Jesus Cristo. Cabe aqui uma última observação quanto a essa autodesignação que os cristãos registraram no livro. Eles viviam por volta da virada dos séculos I e II d.C. e ainda debatiam a importância das leis judaicas para a vida religiosa dentro do cristianismo; esse deve ser o motivo pelo qual o texto faz distinção entre o testemunho de Jesus e os mandamentos de Deus, enfatizando que os destinatários desse livro eram judeus cristãos, e que se distinguiam dos demais judeus porque tentavam conciliar o testemunho de Jesus com a lei de Moisés.

\section{5 - Um Conjunto Literário}

Como já dissemos, o capítulo 12 de Apocalipse é um conjunto literário que apresenta diferentes unidades textuais que procuram descrever um número limitado de eventos a partir de diferentes pontos de vista que se complementam. Até agora nos parece sensato dizer que a elaboração deste capítulo começou com a narrativa maior, que foi dividida no processo redacional. Nesta narrativa principal, tínhamos já uma versão bem completa dos eventos que o autor pretendia registrar (vv. 7-9; 13-17). Porém, conhecia-se outra versão da mesma história, de autoria diferente, mas talvez próxima, que era mais simples e mais curta, e que também foi aproveitada aqui como introdução ao conjunto literário, provavelmente por apresentar os personagens de um modo mais eficiente que a outra versão (vv. 1-6). A união destas duas narrativas não parece suscitar grandes problemas, pois grande parte dos símbolos e motivos empregados na segunda encontra paralelos na primeira. $\mathrm{O}$ resultado final foi um efeito cíclico na composição, pois a narrativa agora terminava repetindo a perseguição do dragão à mulher no deserto, dando a impressão ao leitor de que a história voltara ao seu início.

Não satisfeito, o redator ainda incluiu um hino de vitória que certamente tinha eficácia no uso litúrgico da comunidade cristã primitiva (vv. 10-12). A inclusão dessa unidade cortou ao meio a narrativa principal, mas tal divisão não se deu por acaso. Após se narrar a derrota do dragão para Miguel e seus anjos, o redator encontrou motivos para a celebração, e é por isso que tal hino que comemora a purificação do céu pela expulsão do acusador está aí incluso. Temos então, na sua versão final, um texto emoldurado por duas unidades centradas na terra, no deserto, na situação da mulher... As duas unidades textuais centrais também se relacionam, tratando especialmente dos eventos celestiais, da guerra entre Miguel e o dragão, da vitória sobre o acusador pelo testemunho, e da exultação celeste

pela chegada do reino de Deus. O verbo grego $\beta \alpha \dot{\alpha} \lambda \lambda \omega$ (= lançar) possui destaque ao longo de todo o capítulo; ocorre seis vezes sempre se referindo à derrota de Satanás e seus anjos e à descida deles ao mundo, fornecendo 
outras provas da completude do capítulo. Esses são indícios de que há uma espécie de "fio condutor" que liga as unidades textuais, que provam que as similaridades são mais relevantes que as contradições possivelmente constatáveis.

Curiosamente observamos que em Apocalipse 12 a queda de Satanás não está atrelada diretamente à mulher, o que contradiz boa parte da tradição religiosa judaica. Existem bons estudos que investigam essa tradição para provar que a beleza ou a vaidade feminina eram vistas como as causas da queda dos anjos ${ }^{10}$. Em Apocalipse 12 o mito apresenta a mulher como vítima do dragão somente num momento posterior à queda, não lhe atribuindo qualquer culpa na presença do mal entre a humanidade. É claro que esta é uma conclusão limitada, e que nossas afirmações a esse respeito não devem ser aplicadas ao livro como um todo antes de um exame mais acurado; ainda assim, Apocalipse 12 pode ser colocado nessa discussão ao lado de outros textos sempre abordados como Gênesis 6,1-4, o Livro dos Vigilantes de 1Enoque e a Vida de Adão e Eva, todos testemunhos do paradigma negativo a partir do qual as mulheres eram classificadas nos tempos bíblicos.

\section{1 - Vários Textos, Uma História}

Vejamos agora um novo quadro, onde reapresentamos o texto completo que reorganizamos com a finalidade de facilitar a compreensão das observações feitas acima. A primeira coluna traz a narrativa maior, que é uma versão mais completa e que pode ser dividida em pelo menos dois parágrafos, sendo um centrado na batalha celestial, e outro nos eventos terrenos ocorridos após a queda do dragão. Para destacar esta narrativa, transcrevemo-la em negrito. A segunda coluna traz a outra versão, onde a descrição dos personagens é mais rica, permitindo-nos associar o dragão aos governantes terrenos e a mulher a Israel, assim como é a que trata mais detidamente do Messias. Porém esta sequência narrativa é mais curta, já que não se dedica à batalha entre Miguel e o dragão nas regiões celestes. E finalmente, a terceira coluna traz o hino de vitória que é um acréscimo colocado aqui para expressar a alegria da derrota do inimigo no céu. Nós a colocamos em itálico e entre os dois parágrafos da primeira narrativa, lugar pretendido pelo autor do Apocalipse de João.

\footnotetext{
10 Podemos citar, aqui, dois artigos que investigam as relações entre o sexo feminino e os anjos caídos. O primeiro, de 2001, é de Luigi SCHIAVO, "Como é que é Sentir o Calor?' - A história de Lúcifer que se tornou demônio por causa da mulher”, Estudos Bíblicos 72 (2002) 73-89. O outro artigo é de Paulo A. de Souza NOGUEIRA, Experiência Religiosa e Crítica Social no Cristianismo Primitivo, São Paulo: Paulinas, 2003.
} 


\begin{tabular}{|c|c|c|}
\hline VERSÃO 1 (Céu e Terra) & VERSÃO 2 (Terra) & HINO DE VITÓRIA (Anexo) \\
\hline \multirow[t]{2}{*}{$\begin{array}{l}\text { E fez-se guerra no céu, Miguel } \\
\text { e os anjos dele para guerrear } \\
\text { com o dragão. E o dragão guer- } \\
\text { reou e os anjos dele, e não foi } \\
\text { forte nem lugar foi achado de- } \\
\text { les mais no céu. E foi lançado o } \\
\text { grande dragão, a antiga serpen- } \\
\text { te, chamado Diabo e Satanás, o } \\
\text { que faz errar o mundo todo, foi } \\
\text { lançado para a terra, e os anjos } \\
\text { dele com ele foram lançados. }\end{array}$} & & \\
\hline & & $\begin{array}{l}\text { E ouvi grande voz no céu dizen- } \\
\text { do: Agora veio a salvação e o } \\
\text { poder e o reino do nosso Deus e } \\
\text { a autoridade do Cristo dele. Pois } \\
\text { foi lançado o acusador dos ir- } \\
\text { mãos nossos, o que acusa eles } \\
\text { diante do nosso Deus dia e noi- } \\
\text { te. E eles o venceram por meio } \\
\text { do sangue do cordeiro e por meio } \\
\text { da palavra do testemunho deles } \\
\text { e não amaram a vida deles até a } \\
\text { morte. Por isto alegrem-se, [os] } \\
\text { céus e os que neles habitam. Ai } \\
\text { da terra e do mar, pois desceu o } \\
\text { diabo para vós tendo grande ira, } \\
\text { sabendo que pouco tempo tem. }\end{array}$ \\
\hline $\begin{array}{l}\text { E quando viu o dragão que foi } \\
\text { lançado para a terra, perseguiu } \\
\text { a mulher que pariu o macho. E } \\
\text { foram dadas à mulher as duas } \\
\text { asas da grande águia, para que } \\
\text { voasse para o deserto para o } \\
\text { lugar dela, onde alimentada ali } \\
\text { tempo e tempos e meio tempo } \\
\text { longe da face da serpente. E } \\
\text { lançou a serpente da boca dela } \\
\text { atrás da mulher água como } \\
\text { (uma) torrente, para que ela } \\
\text { levada fizesse. E ajudou a terra } \\
\text { à mulher e abriu a terra a boca } \\
\text { dela e engoliu a torrente a qual } \\
\text { lançou o dragão da boca dela. } \\
\text { E foi irritado o dragão contra a } \\
\text { mulher e foi fazer guerra com } \\
\text { os remanescentes da semente } \\
\text { dela os que guardam os man- } \\
\text { damentos de Deus e têm o tes- } \\
\text { temunho de Jesus. }\end{array}$ & $\begin{array}{l}\text { E sinal grande foi visto no céu, } \\
\text { (uma) mulher tendo vestido o } \\
\text { sol, e a lua debaixo dos pés e } \\
\text { sobre a cabeça dela (uma) coroa } \\
\text { de doze estrelas, e no ventre } \\
\text { tendo, e grita com dores de par- } \\
\text { to e atormentada para parir. E } \\
\text { foi visto outro sinal no céu, e eis } \\
\text { dragão grande vermelho tendo } \\
\text { sete cabeças e dez chifres e so- } \\
\text { bre as cabeças dele sete } \\
\text { diademas, e a cauda dele arras- } \\
\text { ta a terça parte das estrelas do } \\
\text { céu e lançou elas para a terra. E } \\
\text { o dragão para diante da mulher } \\
\text { que estava para parir, para que } \\
\text { quando parisse a criança dela } \\
\text { devorasse. E pariu um filho } \\
\text { macho, o qual vai reger todas as } \\
\text { nações com cetro de ferro. E foi } \\
\text { tomada a criança dela para Deus } \\
\text { e para o trono dele. E a mulher } \\
\text { fugiu para o deserto, onde tem } \\
\text { ali lugar preparado de Deus, } \\
\text { para que ali alimente a ela por } \\
\text { dias mil duzentos (e) sessenta. }\end{array}$ & \\
\hline
\end{tabular}


O quadro nos permite ver, agora de forma mais panorâmica, como a justaposição das unidades textuais formam um quadro bem mais completo do que aquele preexistente que era encontrado na narrativa maior. Entretanto, essa visualização também nos deixa notar alguns problemas. Vimos anteriormente que no hino a vitória sobre o acusador foi resultado da vitória do cordeiro de Deus e dos santos mártires. É provável que tal incongruência tenha sido simplesmente ignorada pelo redator, que simplesmente via-se unindo narrativas que contavam sobre a queda de Satanás, o tema que dá unidade entre as unidades textuais.

A dependência entre as duas unidades que tratam da perseguição à mulher é óbvia. Os motivos que levaram o redator a uni-las, mesmo que isso implicasse em certas redundâncias, também são inteligíveis. Na versão da coluna 1, não há informações sobre o destino nobre do filho da mulher, nem sobre o seu nascimento e nem sobre o seu arrebatamento. Por sua vez, a versão da coluna 2 é mais simples na sua conclusão, não fala com a mesma riqueza de detalhes da fuga da mulher e nem do ataque do dragão a ela no deserto. Em vez de reescrever sua história unindo os detalhes desejados, optou o autor pela união de duas versões já existentes da mesma história.

A comunidade certamente lia este conjunto literário interpretando os símbolos míticos como sugerimos no nosso primeiro capítulo. Satanás, o tentador que outrora fora um anjo, fora lançado na terra por Miguel, e irado, volta sua ira contra o povo de Deus. Ele tem agora o domínio sobre o mundo, e o exerce através dos líderes políticos das nações, dentre as quais, o Império Romano é o mais poderoso. O nascimento do Messias era esperado como uma promessa de transformação milagrosa da realidade, mas como o Messias veio ao mundo indefeso sob a forma humana, Deus o arrebatou para junto de si, a fim de que noutro momento ele voltasse para tomar das mãos de Satanás o controle sobre o mundo. No céu há muitos motivos para celebrar, o reino de Deus é pleno ali, mas na terra a situação continua desesperadora. A comunidade judaico-cristã da diáspora, que julgava ser o verdadeiro Israel, compara-se aos israelitas que peregrinaram pelo deserto nos dias de Moisés. Veem suas provações como sofrimento passageiro, que Deus permitiu que enfrentassem temporariamente. Através dos inimigos humanos, Satanás tenta aniquilá-los de uma vez por todas, mas creem que Deus os livrará de cada investida dele de maneira milagrosa, sustentando-os até que venha o Cristo para definitivamente pôr fim a essa era de trevas. É verdade que alguns desses cristãos podem ver-se diante da necessidade de testemunhar sobre sua fé entregando a própria vida, e é para estarem prontos para todas essas coisas que textos como Apocalipse 12 eram escritos e lidos em suas reuniões litúrgicas. 


\section{Conclusão}

Hesitamos durante todo o trabalho exegético em chamar as unidades textuais que delimitamos de perícopes, posto que numa definição tradicional, uma perícope é uma unidade textual autônoma ${ }^{11}$. Em Apocalipse 12, as unidades textuais são tranquilamente identificáveis, delimitáveis, no entanto, não são autônomas. Apesar de todas as quebras mencionadas, devemos considerar o capítulo 12 do Apocalipse de João como um texto íntegro $^{12}$. É uma compilação consciente e intencional, que talvez siga critérios estranhos para nós, mas que são lógicos e certamente satisfatórios para seu autor ou redator.

Robert Alter escreveu sobre a dificuldade dos intérpretes de hoje em compreender a lógica dos autores bíblicos, que não viam problemas em unir textos que apresentavam elementos contraditórios entre si. Para ele, tal dificuldade deve ser atribuída principalmente à distância histórica e intelectual que nos separa desses autores, que "trabalhavam com noções de unidade bastante diferentes das nossas" ${ }^{\prime 13}$. Comentando casos em que se constata no Antigo Testamento o mesmo fenômeno de justaposição de textos que verificamos em Apocalipse 12, Alter escreveu:

[...] o escritor bíblico, habituado a cortar, juntar e montar com extrema perícia materiais literários anteriores, parece ter tido a intenção de obter esse efeito de verdade multifacetada ao apresentar em sequência duas versões diferentes, que ressaltavam duas dimensões distintas do mesmo assunto $^{14}$.

A metodologia que empregamos parece nos ter conduzido a conclusões coerentes com as opiniões de muitos especialistas modernos que "consideram o Apocalipse de João uma apresentação cíclica de visões que repetem, ou recapitulam, a mesma mensagem básica de perseguição presente, destruição iminente dos maus e recompensa dos justos"15. Ainda assim, acre-

\footnotetext{
${ }^{11}$ Cf. definição de Uwe WEGNER, Exegese do Novo Testamento: Manual de Metodologia, São Leopoldo / São Paulo: Sinodal / Paulus, 1998, 85.

12 MCGINN, “Apocalipse (ou Revelação)", 563-582, aqui 564-565, escreveu sobre a crescente aceitação da integridade literária do Apocalipse dizendo: "Embora a negação da unidade literária tenha triunfado entre os críticos no final do século XIX, ela foi recentemente abalada, a ponto de a maioria dos especialistas sustentar que o Apocalipse é, de fato, o trabalho de um autor, quaisquer que sejam os fragmentos de tradições e materiais anteriores que possa ter incorporado. Desse modo, tanto os especialistas quanto os críticos que acreditam que a passagem do tempo e a intenção do autor afetam o significado de uma obra agora admitem a integridade literária do texto".

${ }^{13}$ R. ALTER, A Arte da Narrativa Bíblica, São Paulo: Companhia das Letras, 2007, 200.

14 Ibid., 210.

15 MCGINN, “Apocalipse (ou Revelação)", 565.
} 
ditamos que nosso trabalho não repetiu as habituais tentativas de transformar o Apocalipse de João numa mera crítica ao Império Romano, e nem tampouco num guia para se desvendar o futuro.

A conclusão dessa nossa experiência exegética pede que a mesma metodologia, se aprovada, seja aplicada na análise de outras porções do Apocalipse de João, a fim de que tais exegeses se complementem. Mesmo que essa metodologia não contribua tanto quanto se deseja com a reconstrução de uma realidade histórica que nos permite compreender como era o cristianismo vivenciado pela comunidade que motivou, criou e utilizou estes textos, sem dúvida ela pode ser de grande valor para a análise do Apocalipse como literatura antiga.

Anderson de Oliveira Lima é mestre e doutorando em Ciências da Religião (Literatura e Religião no Mundo Bíblico) pela Universidade Metodista de São Paulo (2010), Especialista em Bíblia com ênfase na tradição profética também pela Universidade Metodista (2008), e Bacharel em música (violão erudito) pela Universidade Cruzeiro do Sul (1999). Currículo Lattes: http://lattes.cnpq.br/0893915454622475

Endereço: Rua João Franco de Souza, 162 (Vila Jacuí) 08060-280 São Paulo - SP e-mail: aol10@ibest.com.br 